\title{
Comment: Customer lifetime values - credible, or utterly incredible?
}

Tim Ambler

is a senior fellow at the London Business School.

Forget customer relationship management (CRM), the game is now customer lifetime value (CLV). As a marketer with a healthy interest in profits, I regard CLV as an interesting idea, but do not throw out your traditional marketing textbooks just yet. In some respects, CLV is a glimpse of the obvious: live customers are more profitable than dead ones. And that goes for undertakers; the customers are the people who pay the bill. The question is what the Customer Lifetime Value concept contributes that we did not already know.

Large firms have been calculating customer profitability, either individually or by customer segment, for at least 30 years. The new insight, apparently, is that firms should determine the profitability of each customer over the relationship lifetime by calculating the net present value of future cash flows. Then, they say, we should allocate resources in proportion to the CLV of each customer. Those with a negative CLV should receive no investment or better, be gently directed to the exit.

Intuitively, this is an attractive idea. It puts the emphasis on customer retention rather than customer acquisition, particularly on retention of the most valuable customers. The virtuous circle should operate with more resources in the right place leading to more satisfaction leading to retention and then to acquisition of the right kind of customers as these most valuable customers pass the word to their peers. This will save expensive prospecting.
Furthermore, marketers can express this strategy to colleagues in their own language - money. The cash flows should mesh tidily with those used for shareholder value and brand valuation.

So, a nice concept. But, like many great ideas, this one looks better on the drawing-board than in practice. Let's take a look at exactly how CLV is calculated. We first need to know how long each customer relationship will last; what competitive products will enter the market and each customer's reaction in terms of their purchasing patterns (how much they will buy, of which products from our portfolio, how often and at what prices); economic and environmental conditions over a few generations; what your brand and other marketers will do then; interest rates and, of course, what new customers will come on board and when. I do not mean to be churlish but if I had that level of forecasting skill, I would be at the races.

Of course, CLV fans take short cuts. They aggregate customers into segments usually according to current profitability. In almost any business something like 20 per cent of customers contribute about 80 per cent of profit. Despite excited claims to the contrary, that is not a new discovery. The High Street banks decided to focus on the wealth segment which was largely 50-year-olds whose parents had just died. In the manner of High Street banks they all did this around the same time and rather hamfistedly. Customers were unimpressed. The fallacy is that the current relative profitability will always remain 
true. Projecting the present into the future may be a decent estimation but it does not add any new information.

The marketing challenge is not how to milk profitable customers but how to make customers more profitable. The irredeemably unprofitable customers will have to be addressed; but, be careful. She may be your best customer's aunt and customers talk to one another. The usual solution has much to commend it: explain the problem and put the price up.

I used to think that brand valuation and shareholder value techniques, in moderation, were admirable. Now I am not so sure. CLV shares with these an excessive dependency on the future. To the extent that bad marketing practices are being justified by future fantasies, these techniques are downright pernicious.

We need to distinguish the justification of a single strategy on the basis of these forecasts from the comparison of alternative plans. The forecasters are on much stronger ground in the latter case because most of the assumptions are the same for both cases. Thus we cannot use CLV to prove a plan but we can say that Plan A is more likely to be better than Plan B.

Marketers need to remember that they cannot measure the future. The nearest to the future they can get is today. That is why market metrics are so much more important than shareholder value projections. Yes, it is difficult to interpret what current customer attitudes and behaviours will mean for future sales but at least the feet are firmly in reality. Furthermore, one can track back to earlier data and see what happened then.

Here-and-now numbers are credible and never-never numbers are not. We need to be far more aware than we seem to be that forecasts are almost all wrong. Marketing decisions based on never-never numbers that pile assumptions on top of estimates are little better than a blindfold darts match.
The better way to judge marketing expenditure and practice is to use the effects on brand equity. Of course we should look at profit and loss account effects as well but the marketing asset, brand equity, is what matters. Deciding how to measure it is how we describe what it is. Every firm has some mental model of where the cash comes from but this is usually tacit. We need to draw that into the limelight. What are the market metrics which track progress? We need to describe brand equity, and how it grows, before valuing it, or CLV come to that.

The bridge between the two is now called 'customer equity' which is the same asset seen from a customer perspective. For a single brand company, the sum of all its customer equities is the same as its brand equity but, just as the sales and brand perspectives should lead to stronger marketing campaigns, so taking both brand and customer perspectives of the marketing asset will describe it better.

We have returned to the original question. CLV can be pernicious if the logic is followed remorselessly but the customer perspective and segmentation give important perspectives on the marketing decisions that matter today. Intangibility is not an issue. If the finance director says $s /$ he cannot see, or kick, brand equity, then ask him to kick the balance in the current account. $f 10 \mathrm{~m}$ in a bank account is not made real by forecasting how you will spend it but by its existence today. Brand equity is not made tangible by the profits it may generate in 20 years, as expressed in CLV, but by the extent to which you can measure it now.

CLV, shareholder value and these other techniques require managers to live in the future, not the present. Ignore the CLV fad. It will pass soon enough and you will not have risked your own lifetime values in the process. Focus on what customers want, build the brand to provide it, and the profits will look after themselves. 